\title{
Application of Cloud Point Method for Spectrophotometric Determination of Salbutamol Sulphate and Methyldopa
}

\author{
Intisar A. Shihab ${ }^{1}$ and Theia'a N. Al-Sabha ${ }^{2 *}$ \\ ${ }^{1}$ Department of Chemistry, College of Education for Girls, University of Mosul, Mosul, Iraq. \\ ${ }^{2}$ Department of Chemistry, College of Education for Pure Sciences, University of Mosul, Mosul, Iraq. \\ *Corresponding Author Email: dr_theiaa@yahoo.co.uk \\ Received 12 February 2019, Revised 17 January 2020, Accepted 30 May 2020
}

\begin{abstract}
A simple and efficient cloud point spectrophotometric method has been used for the determination of salbutamol sulphate and methyldopa both in pure and pharmaceutical preparations. The procedure was based on the ion association formation with eosin Y. The extraction of ion association, drown to Triton X-114 micelles, was measured spectrophotometrically. The phase separation was studied and optimized. Beer's law was rectilinear over the concentration ranges of $0.1-20$ and $0.3-10 \mu \mathrm{g} / \mathrm{mL}$ with molar absorptivity $4 \times 10^{4}$ and $5.7 \times 10^{4} \mathrm{~L}_{\mathrm{mol}}{ }^{-1} \mathrm{~cm}^{-1}$ and average recovery $98.21 \%$ and $101.27 \%$ for the above drugs, respectively. The method was applied successfully for the determination of salbutamol sulphate and methyldopa in pharmaceuticals.
\end{abstract}

Keywords: Cloud point, Ion association, Eosin Y, Salbutamol, Methyldopa.

\section{Introduction}

Methyldopa [L $\alpha$-Methyl-3,4-dihydroxyphenylalanine; $\mathrm{C}_{10} \mathrm{H}_{13} \mathrm{NO}_{4}$ ] [I] is an aromatic-amino acid decarboxylase inhibitor in animals and in man [1]. It is a medication that has been used to treat high blood pressure since the 1960s. While there is some belief that it reduces blood pressure [2]. Salbutamol, [1-(4-hydroxy-3-hydroxymethylphenyl)-2-(t-butylamino) ethanol] (II), marketed as Ventolin, is usually considered the drug of choice as relief medication for symptoms of bronchospasm. It is an agonist of $\beta 2$ receptors which are present in the bronchioles of lungs of the human body. Athletes using $\beta 2$-agonists, usually inhale them prophylaxis prior to competition or training [3].<smiles>N[C@@H](Cc1ccc(O)c(O)c1)C(=O)O</smiles><smiles>CC(C)(C)NCC(O)c1ccc(O)c(CO)c1</smiles>

For the determination of salbutamol sulphate and methyldopa, different analytical techniques have been proposed, like spectrophotometric [4-15], chromatographic [1619], voltammetric [20-21], potentiometric [22], flow injection [23] and kinetic [24] methods. Our determination of salbutamol sulphate and methyldopa spectrophotometrically is actually new, simple, and sensitive. The method has been applied for the determination of the pharmaceutical formulations of both drugs. The work has aimed at developing a new spectrophotometric method with cloud point extraction (CPE) preconcentration for Salbutamol and Methyldopa by using of eosin $\mathrm{Y}$ as a reagent. In the CPE method, surfactant Triton X-114 was used as the extractant solution which is used for promoting phase separation [25].

\section{Materials and Methods}

Visible spectrophotometer (T92 UV) equipped with a $1.0-\mathrm{cm}$ glass cell and RLO 60P $\mathrm{pH}$-meter with a combined glass electrode has been used. A centrifuge was used for separation 
(laboratory centrifuge-INDIA). Statistically, Excel 2010 software has been used.

\section{Reagents}

In this research, the chemical materials used were from Fluka and BDH companies. eosin $\mathrm{Y}$ concentrations of $1 \%$ and $2 \%$ were prepared by diluting 1 and $2 \mathrm{~g}$ in distilled water respectively, using calibrated flasks of volume $100 \mathrm{~mL}$. The acetate and citrate buffer solutions of $\mathrm{pH} 3.9$ and 4 were adjusted by $\mathrm{pH}$ meter. Salbutamol sulphate and methyldopa of $100 \mu \mathrm{g} / \mathrm{mL}$ were prepared by diluting of $0.01 \mathrm{~g}$ of each pure drug in $100 \mathrm{~mL}$ distilled water separately. Triton X-100 of $1 \%$ was prepared by dissolving $1 \mathrm{~g}$ of surfactant in $100 \mathrm{~mL}$ distilled water in volumetric flask.

\section{General cloud point extraction procedure for drugs}

Into two sets of $10 \mathrm{~mL}$ volumetric flasks, volumes of both salbutamol and methyldopa within concentrations $0.1-20$ and $0.3-10 \mu \mathrm{g} / \mathrm{mL}$ respectively, were added separately. Then, followed by the addition of $1 \mathrm{~mL}$ of citrate buffer or acetate buffer solution, $1 \mathrm{~mL}$ of $1 \%$ Triton $\mathrm{X}$ 114 followed by addition of $2 \mathrm{~mL}$ of $1 \%$ eosin $\mathrm{Y}$ for salbutamol or methyldopa, respectively. Then, the volume was completed to the mark with distilled water. The solutions were placed in a water bath adjusted at $60^{\circ} \mathrm{C}$ or $50^{\circ} \mathrm{C}$ for above drugs respectively. The turbid contents of the flasks were transferred into a $10 \mathrm{~mL}$ centrifuging tubes. Surfactant-rich phase were accomplished by centrifugation for $10 \mathrm{~min}$ at $3500 \mathrm{rpm}$. After cooling in an ice bath for $5 \mathrm{~min}$ the rich layer became sticky, and the aqueous phases were decanted. Ethanol was added to surfactant-rich phase and the volume was completed to $10 \mathrm{ml}$ by distilled water. The absorbance was measured at $558 \mathrm{~nm}$ and $564 \mathrm{~nm}$ for salbutamol and methyldopa, respectively.

\section{Results and Discussion}

The preliminary investigation was found that salbutamol and methyldopa reacted with Eosin $\mathrm{Y}$ in acidic medium, a reddish-orange ionpair complexes with $\lambda_{\max }$ at $558 \mathrm{~nm}$ and $564 \mathrm{~nm}$ respectively (Fig. 1) as a result of the reaction.
Which attributed to the electrostatic interaction between the most basic center in the drug's molecules (hydroxyl groups) and the carboxylate anion of the dye formed complexes.

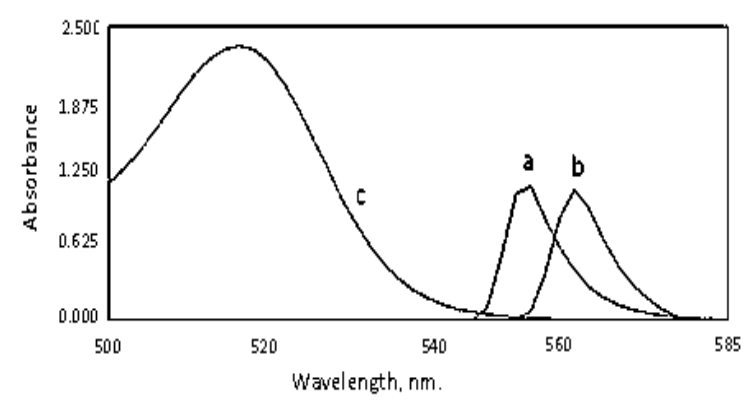

Figure 1. Absorption spectra of $3 \mu \mathrm{g} / \mathrm{mL}$ methyldopa (a) and 10 $\mu \mathrm{g} / \mathrm{mL}$ salbutamol (b) with Eosin against reagent blank (c) under optimum conditions

\section{Optimization of reaction conditions}

High sensitivity was achieved via different parameters influences such as $\mathrm{pH}$, reagent concentration, temperature and developing time.

\section{Effect of pH and buffer solution}

The effect of $\mathrm{pH}$ for the reaction of salbutamol sulphate and methyldopa was studied with eosin $\mathrm{Y}$ in the acidic medium by adding increasing amounts of hydrochloric acid with a concentration of $1 \mathrm{M}$. It has been found that the maximum absorption was reached at $\mathrm{pH} 4$ by adding $2 \mathrm{~mL} \mathrm{HCl}$ for both drugs (Fig. 2). Different types of buffers such as acetate, phthalate, glycine and citrate buffers, with the same values of $\mathrm{pH} 4$ have been studied. It was observed that maximum absorption on using citrate buffer for salbutamol, and acetate buffer for methyldopa with quantities of 1 and $2 \mathrm{~mL}$, respectively (Fig. 3).

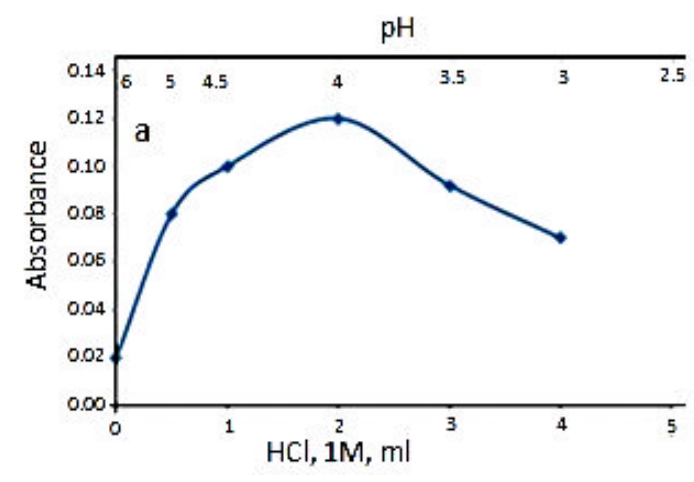




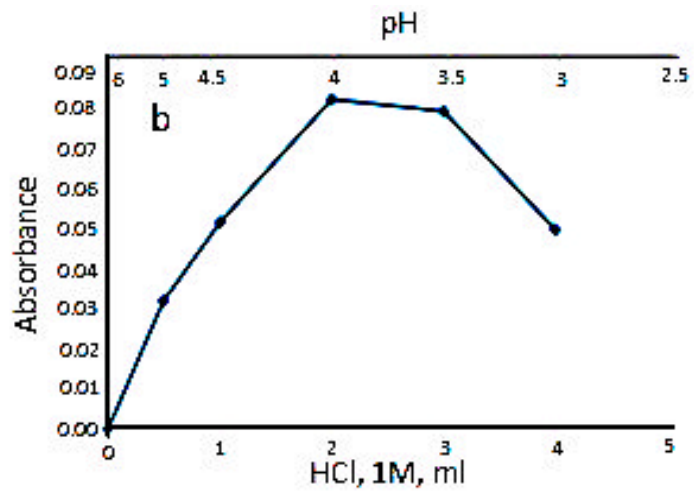

Figure 2. Effect of $\mathrm{pH}$ on the absorbance of $3 \mu \mathrm{g} / \mathrm{mL}$ methyldopa (a) and $3 \mu \mathrm{g} / \mathrm{mL}$ salbutamol (b) in the presence of $1 \mathrm{~mL}$ of $1 \%$ eosin $\mathrm{Y}$ and $\mathrm{HCl}$.

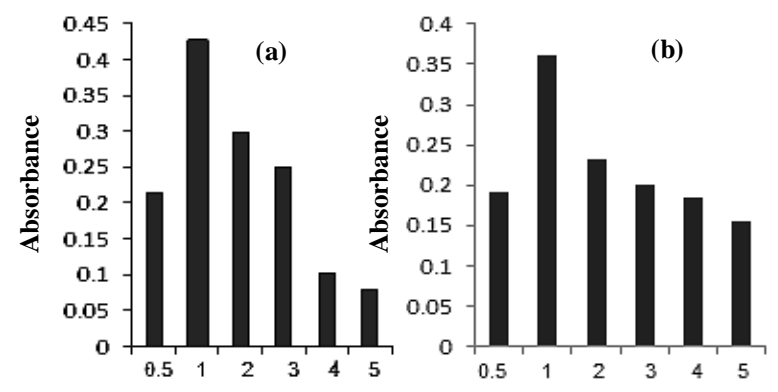

Acetate buffer solution, $\mathbf{m L} \quad$ Citrate buffer solution, $\mathbf{m L}$

Figure 3. Effect of buffer solution on the absorption of (a) methyldopa and (b) salbutamol

\section{The effect of eosin Y concentration}

Different concentrations of $2 \mathrm{~mL}$ eosin $\mathrm{Y}$ have been studied. It was found that $1 \%$ and $2 \%$ concentrations gave maximum absorbance for ionpair complexes of salbutamol and methyldopa, respectively. However; different quantities of these concentrations have been added to the solutions and found that, $2 \mathrm{~mL}$ for both drugs gave maximum absorbance respectively as seen in Fig. 4.

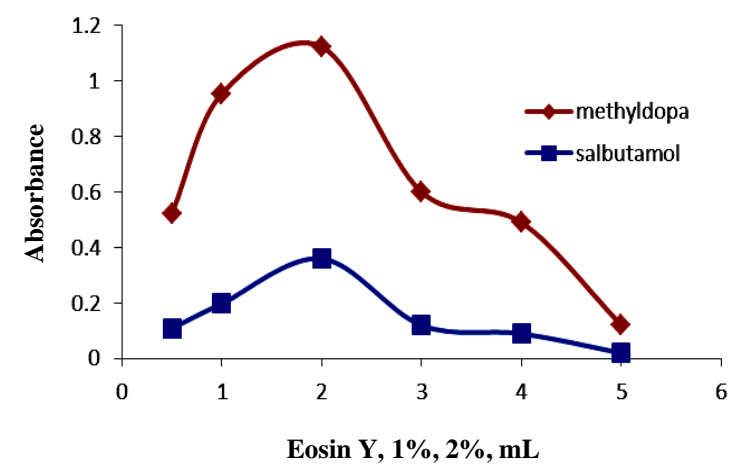

Figure 4. Effect of $1 \%$ and $2 \%$ eosin $Y$ volume on the absorbance of salbutamol and methyldopa, respectively

\section{Effect of triton $X-114$ surfactant concentration}

The effect of Triton X-114 concentration on the efficiency of extraction has been studied. The extraction efficiency increases with increasing the concentration of the surfactant and gave maximum sensitivity at concentration $1 \% \mathrm{v} / \mathrm{v}$ for both drugs (Fig. 5). However; it was found that 2 $\mathrm{mL}$ and $1 \mathrm{~mL}$ of surfactant gave maximum absorbance for salbutamol and methyldopa, respectively, which are recommended in the next experiments (Fig. 6).

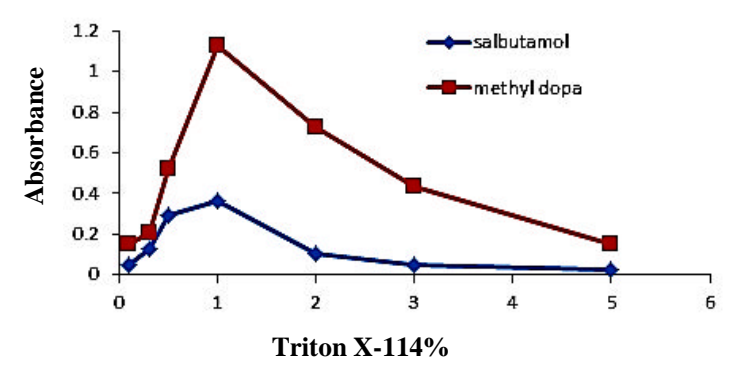

Figure 5. Effect of Triton X-114\% on the absorbance of salbutamol and methyldopa

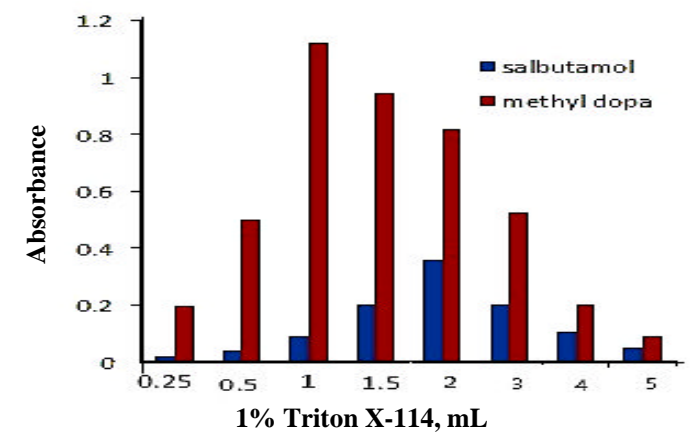

Figure 6. Effect of $1 \%$ Triton $\mathrm{X}-114$ volume on the absorbance of salbutamol and methyldopa

\section{Effect of the centrifugation time}

The effect of the centrifugation time on extraction efficiency was studied within a range of 1-30 min. It has been found that the separation is not completed until $10 \mathrm{~min}$ at $3500 \mathrm{rpm}$ which was selected in this procedure (Fig. 7).

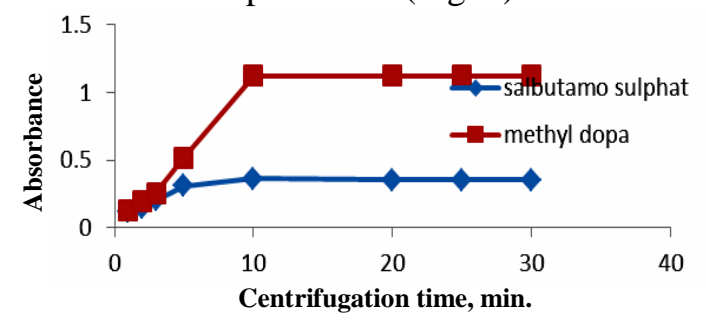

Figure 7. Effect of centrifugation time 


\section{The effect of time and temperature}

Equilibration temperature and optimal incubation time are necessary to achieve complete extraction and easy phase separation. The effect of temperature, ranging from room temperature up to $70^{\circ} \mathrm{C}$, has been studied. An optimum of $50^{\circ} \mathrm{C}$ and $60^{\circ} \mathrm{C}$ were selected for salbutamol and methyldopa, respectively. The extraction efficiency upon equilibration time was studied within a range of 5-90 min. It was found that complexes were formed within $20 \mathrm{~min}$, which is selected as the best, and remained stable for 50 min and $60 \mathrm{~min}$ for above drugs respectively, (Fig. 8a \& 8b).

\section{Composition and stability constant of the ion-pair complexes}

The composition of the ion-pair was studied by Job's of continuous variation [26] and slop ratio methods [27] using equimolar solutions of $1 \times 10^{-3} \mathrm{M}$ of each drug and eosin $\mathrm{Y}$. The results shown in Fig. 9 indicated that the ion-pair complexes were formed in the ratio of $1: 1$. The apparent stability constant was estimated by comparing the absorbance of a solution containing stoichiometric amounts of the drug and eosin $\mathrm{Y}$ (As) to one containing an optimum amount of eosin $\mathrm{Y}$ reagent $(\mathrm{Am})$. The average conditional

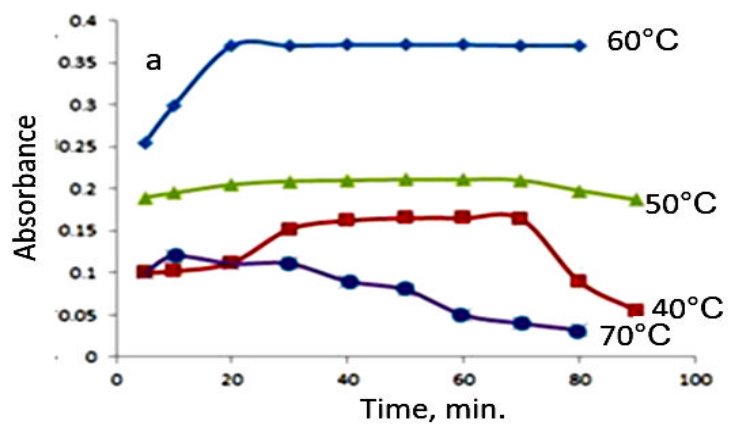

stability constant of the complexes was calculated, according to the $1: 1$ ratio, by the following equations:

$$
\mathrm{Kc}=1-\alpha / \alpha^{2} \mathrm{C} \quad \alpha=\mathrm{Am}-\mathrm{As} / \mathrm{Am}
$$

Where $\mathrm{Kc}$ is the stability constant $\left(1 . \mathrm{mol}^{-1}\right), \alpha$ is dissociation degree and $\mathrm{C}$ the concentration of the complex which is equal to the concentration of the drug. The average stability constants for three different concentrations were found $7.4 \times 10^{6}$ and $1.6 \times 10^{6} 1 . \mathrm{mol}^{-1}$ for salbutamol and methyldopa respectively indicating the good stabilities.

\section{Mechanism}

The ion-pair complexes were formed via electrostatic interaction between the amino group present in drug molecule and carboxylate anion of eosin $\mathrm{Y}$ in an acidic medium which increasing the electron delocalization of eosin $\mathrm{Y}$ and a red shift of the dye about 40-50 nm was occurred, (Fig. 1). Applying slope ratio and Job's methods (Fig. 9), it was found that, the reaction proceeds in the ratio of 1:1 of drug to eosin Y for both drugs, as seen in their chemical structures, they have one basic center, the proposed mechanism of the reaction pathway is shown in Scheme 1.

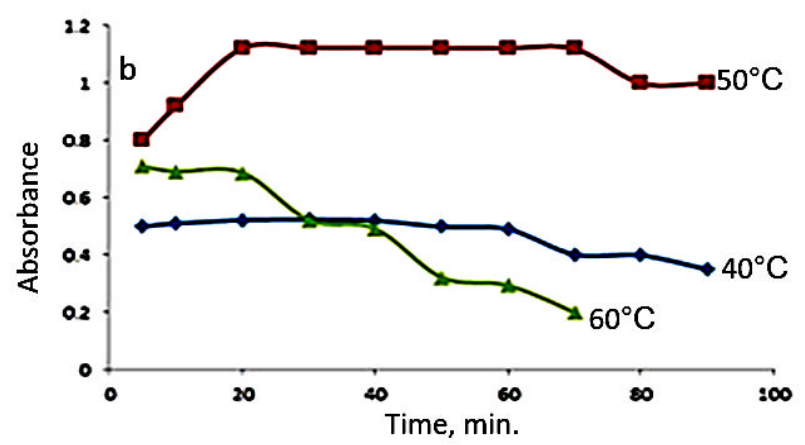

Figure 8. ffect of equilibration temperature and time on the absorption of $3 \mu \mathrm{g} / \mathrm{mL}$ for each of salbutamol (a) and methyldopa (b) with eosin Y

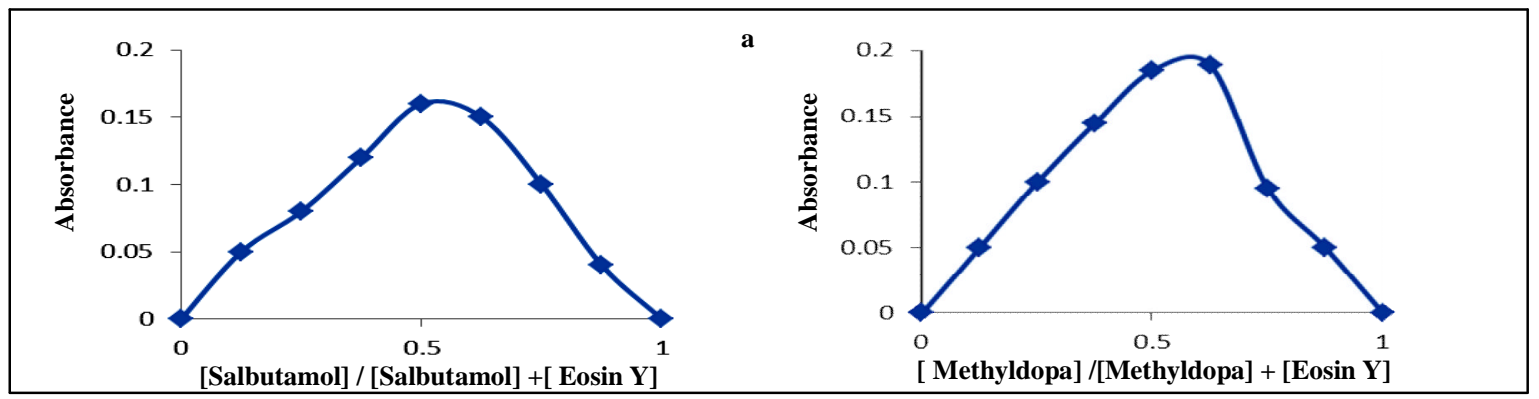



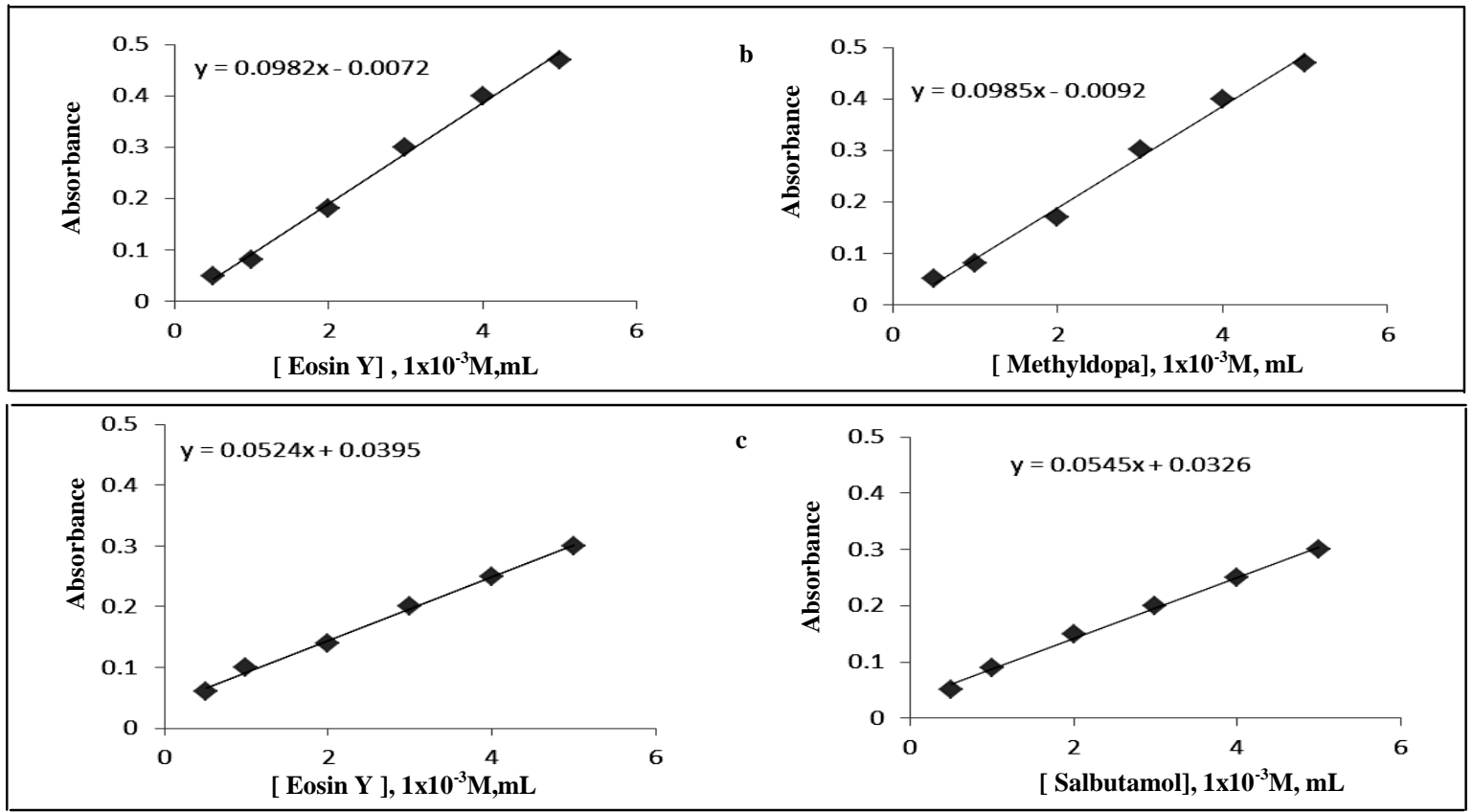

Figure 9. Job's method for salbutamol and methyldopa (a) and slope ratio method for methyldopa (b) and salbutamol (c) ion pair complexes with eosin $\mathbf{Y}$
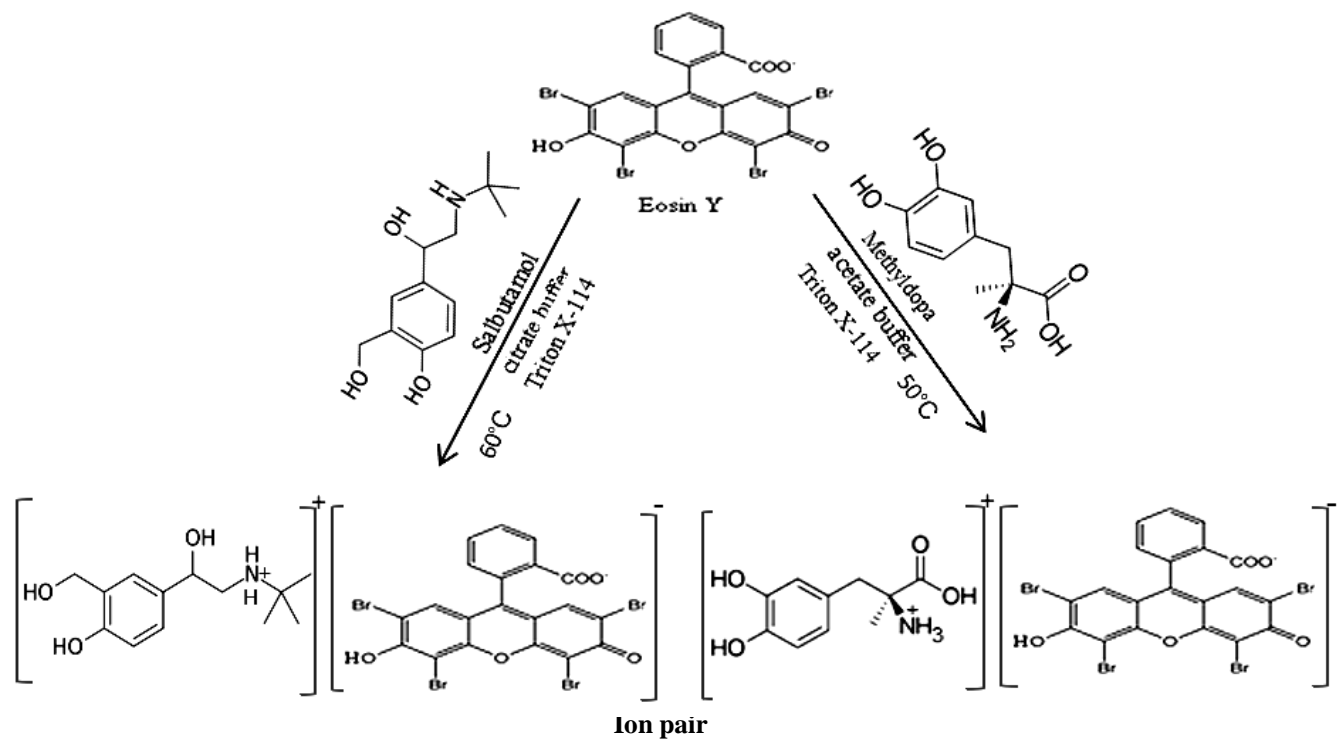

Scheme 1. Suggested mechanisms of the reaction between salbutamol and methyldopa with eosin Y.

\section{Linearity and range}

Linear relationships actually found between the absorbance and the concentration of the drugs in the ranges $0.1-20$ and $0.3-10 \mu \mathrm{g} / \mathrm{mL}$ with molar absorptivity values $4 \times 10^{4}$ and $5.79 \times 10^{4}$ L. $\mathrm{mol}^{-1} \cdot \mathrm{cm}^{-1}$ for salbutamol and methyldopa respectively, indicating the method is sensitive.
The linearity was represented by the regression equation and the corresponding correlation coefficient for the studied drug by the proposed method represents excellent linearity. Five replicates of each three different concentrations for each drug were determined. The relative standard deviation and accuracy indicated that the method is precise and accurate. Limit of detection (LOD) 
and limit of quantitation (LOQ) were then calculated. However; the analytical parameters for the proposed method are shown in Table 1.

Table 1. Summary of optical characteristics and statistics data for the proposed method.

\begin{tabular}{lcc}
\hline \multicolumn{1}{c}{ Parameter } & Salbutamol & Methyldopa \\
\hline$\lambda_{\max }(\mathrm{nm})$ & 558 & 564 \\
Linear range $(\mu \mathrm{g} / \mathrm{mL})$ & $0.1-20$ & $0.3-10$ \\
Molar absorptivity $\left(\mathrm{L} \cdot \mathrm{mol}^{-1} \cdot \mathrm{cm}^{-1}\right)$ & $4 \times 10^{4}$ & $5.79 \times 10^{4}$ \\
LOD $(\mu \mathrm{g} / \mathrm{mL})$ & 0.041 & 0.0165 \\
LOQ $(\mu \mathrm{g} / \mathrm{mL})$ & 0.139 & 0.055 \\
Average recovery* $(\%)$ & 98.21 & 101.27 \\
Regression equation $(\mathrm{Y})^{* *}$ & & \\
Slope, a & 0.0962 & 0.2435 \\
Intercept, b & 0.0749 & 0.336 \\
RSD* & $\leq 1.6$ & $\leq 0.3$ \\
\hline
\end{tabular}

*Average for five determinations

$* * \mathbf{Y}=\mathbf{a X}+\mathbf{b}$, where $\mathbf{X}$ is the concentration of salbutamol and methyldopa in $\mu \mathrm{g} / \mathrm{mL}$

\section{Specificity}

The specificity of the method was investigated by the observation of any interference encountered from the common excipients of the pharmaceutical formulations by the measurement of the absorbance of solutions containing $3 \mu \mathrm{g} / \mathrm{mL}$ for each of drugs, and various amounts of different additives, up to $200 \mu \mathrm{g} / \mathrm{mL}$ for salbutamol and methyldopa respectively, in a final volume of 10 $\mathrm{mL}$. It was found that the studied excipients did not interfere seriously (Table 2).

\section{Analytical applications}

The proposed method was successfully applied to determine salbutamol sulphate (tablet, spray, and syrup) and methyldopa tablet in their pharmaceutical formulations, using three different concentrations for each formulation. The average recovery (\%) was in the range $99.84-102.60 \%$ for salbutamol sulphate and 98.95-100.50 \% for methyldopa indicating that the method is accurate (Table 3). The obtained results of methyldopa tablet and salbutamol sulphate tablet were compared statistically by a Student's t-test for accuracy and a variance ratio F-test for precision with the official method procedure [28] at the $95 \%$ confidence level with four degrees of freedom. The results showed that the experimental $\mathrm{t}$-test $=$ $1.272,1.350$ and F-test $=4.38,4.303$, for above drugs respectively, were less than the theoretical value ( $\mathrm{t}=4.303, \mathrm{~F}=9.28)$, indicating that there was no significant difference between the proposed method and official method.

\section{Comparison of the present method with other spectrophotometric methods}

The present spectrophotometric method has been compared with other spectrophotometric methods for determination of salbutamol and methyldopa. These methods are depended on the reduction of gold to gold nanoparticles in the presence of SDS surfactant for determination of salbutamol [29], 2,6-dichloroquinone-4-chlorimide (DCQ) in the medium of acetate buffer as coupling reagent for determination of methyldopa [30], and application of cloud point extraction in oxidative coupling reaction for determination of methyldopa and salbutamol using thiosemicarbazide and 4-nitrophenyl hydrazine respectively [15]. As seen in Table 4, the suggested method is more sensitive, accurate and precise than other methods.

Table 2. Effect of excipients for assay of salbutamol and methyldopa.

\begin{tabular}{|c|c|c|c|c|c|c|c|c|}
\hline \multirow[t]{2}{*}{ Excipient } & \multicolumn{4}{|c|}{$\begin{array}{c}\text { Recovery\% of } 3 \mu \mathrm{g} / \mathrm{mL} \text { methyldopa per } \mu \mathrm{g} / \mathrm{mL} \\
\text { excipient }\end{array}$} & \multicolumn{4}{|c|}{ Recovery $\%$ of $3 \mu \mathrm{g} / \mathrm{mL}$ salbutamol per $\mu \mathrm{g} / \mathrm{mL}$ excipient } \\
\hline & 20 & 50 & 100 & 200 & 20 & 50 & 100 & 200 \\
\hline Glucose & 104.55 & 104.46 & 100.44 & 110.8 & 100.79 & 100.0 & 100.0 & 100.50 \\
\hline Lactose & 104.46 & 100.02 & 116.07 & 108.99 & 99.69 & 100.20 & 99.39 & 96.60 \\
\hline Starch & 100.08 & 100.35 & 107.14 & 107.2 & 101.30 & 100.69 & 10.0 & 90.09 \\
\hline Arginine & 98.03 & 100.80 & 101.60 & 97.75 & 100.02 & 100.39 & 99.69 & 98.69 \\
\hline $\mathrm{NaCl}$ & 104.64 & 104.73 & 100.0 & 108.92 & 99.90 & 100.0 & 99.39 & 91.39 \\
\hline Acacia & 100.44 & 100.26 & 100.0 & 106.4 & 100.0 & 100.0 & 102.3 & 94.70 \\
\hline
\end{tabular}


Table 3. Assay of salbutamol sulphate and methyldopa in pharmaceutical preparations.

\begin{tabular}{|c|c|c|c|c|}
\hline $\begin{array}{c}\text { Pharmaceutical } \\
\text { formulation }\end{array}$ & $\begin{array}{c}\text { Drug amount present } \\
(\mu \mathrm{g} / \mathrm{mL})\end{array}$ & $\begin{array}{c}\text { Recovery }^{*} \\
(\%)\end{array}$ & $\begin{array}{l}\text { Average drug content } \\
\text { found (mg) }\end{array}$ & $\begin{array}{c}\text { Certified value } \\
\text { (mg) }\end{array}$ \\
\hline \multirow{4}{*}{$\begin{array}{l}\text { Salbutamol sulphate } \\
\text { tablet }^{\text {a }}\end{array}$} & 5 & 104.00 & \multirow{3}{*}{2.031} & \multirow{3}{*}{2.0} \\
\hline & 10 & 102.00 & & \\
\hline & 15 & 98.66 & & \\
\hline & 5 & 102.80 & \multirow{3}{*}{2.032} & \multirow{3}{*}{2.0} \\
\hline \multirow[t]{2}{*}{ Butadin $^{a}$} & 10 & 103.40 & & \\
\hline & 15 & 98.60 & & \\
\hline \multirow{3}{*}{ Aldosam $^{a}$} & 0.8 & 100.00 & \multirow{3}{*}{250.350} & \multirow{3}{*}{250} \\
\hline & 3 & 103.33 & & \\
\hline & 10 & 97.10 & & \\
\hline \multirow{3}{*}{ Salbu Vent ${ }^{\mathrm{b}}$} & 5 & 101.00 & \multirow{3}{*}{$0.502 \%$} & \multirow{3}{*}{$0.5 \%$} \\
\hline & 10 & 102.00 & & \\
\hline & 15 & 98.66 & & \\
\hline \multirow{3}{*}{ Alfamet $^{c}$} & 0.8 & 103.75 & \multirow{3}{*}{258.25} & \multirow{3}{*}{250} \\
\hline & 3 & 103.33 & & \\
\hline & 10 & 97.20 & & \\
\hline
\end{tabular}

*Average of four determinations

${ }^{\mathrm{a}} \mathrm{SDI},{ }^{\mathrm{b}}$ Diamond pharma-Damascus, ${ }^{\mathrm{c}}$ Turkey-Cyprus

Table 4. Comparison of the present method with other methods.

\begin{tabular}{|c|c|c|c|c|c|c|}
\hline \multirow[t]{2}{*}{ Analytical Parameters } & \multicolumn{2}{|c|}{ Present method } & \multicolumn{4}{|c|}{ Reported methods } \\
\hline & Salbutamol & Methyldopa & $\begin{array}{c}\text { Salbutamol } \\
\text { [29] }\end{array}$ & $\begin{array}{c}\text { Methyldopa } \\
{[30]}\end{array}$ & $\begin{array}{c}\text { Salbutamol } \\
{[15]}\end{array}$ & $\begin{array}{c}\text { Methyldopa } \\
{[15]}\end{array}$ \\
\hline$\lambda_{\max }$ & 558 & 564 & 530 & 400 & 535 & 470 \\
\hline Linearity $(\mu \mathrm{g} / \mathrm{mL})$ & $0.1-20$ & $0.3-10$ & $5.0-18.0$ & $4-20$ & $0.25-6$ & $0.25-6$ \\
\hline Development (time, min) & 15 & 15 & 20 & 60 & 50 & 50 \\
\hline Recovery $(\%)$ & 98.21 & 101.27 & 97.20 & 101.7 & 99.98 & 99.57 \\
\hline Molar absorptivity & $4 \times 10^{4}$ & $5.79 \times 10^{4}$ & $1.46 \times 10^{4}$ & $6.42 \times 10^{3}$ & $4.83 \times 10^{4}$ & $5.10 \times 10^{4}$ \\
\hline \multicolumn{7}{|l|}{$\left(\mathrm{L} \cdot \mathrm{mol}^{-1} \cdot \mathrm{cm}^{-1}\right)$} \\
\hline $\mathrm{LOD}(\mu \mathrm{g} / \mathrm{mL})$ & 0.041 & 0.0165 & 1.625 & 1.1 & 0.029 & 0.024 \\
\hline LOQ $(\mu \mathrm{g} / \mathrm{mL})$ & 0.139 & 0.055 & 4.924 & 3.21 & 0.098 & 0.079 \\
\hline $\operatorname{RSD}(\%)$ & $\leq 1.55$ & $\leq 0.23$ & 1.216 & 0.84 & $\leq 0.23$ & $\leq 0.18$ \\
\hline
\end{tabular}

\section{Conclusion}

For the determination of salbutamol sulphate and methyldopa, a simple, accurate and precise spectrophotometric method was developed. The method depended on the formation of ion-pair complexes between eosin Y dye and the drugs followed by cloud point extraction with Triton X-114 surfactant. Statistics indicated the high reproducibility and accuracy of the suggested method. Analysis of samples showed that there is no interference from common additives and auxiliary substances. The advantage of the method is less time-consuming and requiring no variety of elaborative treatments and tedious extraction procedures as well as the capability of successful application of pharmaceutical preparations.

\section{Acknowledgment}

The Authors would like to express their gratitude to the department of chemistry, College of Education for Pure Science, University of Mosul for using their laboratories and providing us the chemicals to carry out the research work. 


\section{References}

1. A. C. Moffat, M. D. Osselton and B. Widdop, Clarke's Analysis of Drug and Poisons in pharmaceuticals, body fluids and postmortem material, $4^{\text {th }}$ Ed. Pharmaceutical Press, Inc, London, (2011) 1672.

2. G. T. Mah, A. M. Tejani and V. M. Musini, Methyldopa for primary hypertension (Review), Cochrane Database of Systematic Reviews 2009, John Wiley \& Sons, Ltd, (2010). doi: 10.1002/14651858.CD003893.pub3.

3. O. J. Price, J. H. Hull, V. Backer, M. Hostrup and L. Ansley, Sports Med., 44 (2014) 1749.

doi: 10.1007/s40279-014-0238-y

4. R. D. Kaushik, R. Yadav, Sushma, Manila and J. Singh, Der Pharma Chemica, 6 (2014) 102. ISSN 0975-413X

5. V. B Bharkad, H.N Khan, A. G Mangulkar, M.D Zameeruddin, S.V. Jadhav and P. Katakam, Int. J. Pharm. Anal. Res., 6 (2017) 449.

http://www.ijpar.com/articles/2017/6/3

6. M. J. M. Hassan and T. J. Al- hraishawi, Int. J. Chem. Tech. Res., 10 (2017) 756.

ISSN(Online):2455

7. K. F. Faris, E.T.A. Al Samarrai And B.A Al samarrai, Int. J. Res. Pharm. Sci., 10 (2019) 1367.

doi:10.26452/ijrps.v10i2.542

8. D. Satinsky, R. Karlicek and A. Svobada, Anal. Chim. Acta, 455 (2002) 103. doi: 10.1016/S0003-2670(01)01586-0

9. N. El-Enany, F. Belal and M. Rizk, Chem. Anal., 1 (2004) 261.

10. L. Kalyani and C. V. N. Rao, Karb. Int. J. Mod.Sci.,4 (2018) 171. doi.org/10.1016/j.kijoms.2018.01.004

11. M. A. Goiardo, L.S. Lima, R. SequmeJ, J. L. Ruiino, L. Fezza and H. R. Pezza, Ecieiica Quimica, 33 (2008) 7. doi: 10.1590/s0100-46702008000300001.

12. M. A. Al-Da'amy and R. F. Al-Moswi, Chem. Mater. Res., 3 (2013) 31. doi: 10.21123/bsj.2017.14.1.0181
13. K. Basavaiah and H. C. Prameela, Anal. Bioanal. Chem., 376 (2003) 879. doi 10.1007/s00216-003-1972-4

14. E. A. Gadkariem, K. E. Ibrahim, N. A. Kamil, M.E. Haga and H. A. El-Obeid, SPJ, 17 (2009) 289. doi: 10.1016/j.jsps.2009.10.005

15. N. K. Abood, M. J. M. Hassan and M. A. AL-Da'amy, Int. J. Drug Del. Tech., 9 (2019) 182. doi: 10.25258/ijddt.9.2.11

16. R. N. Gupto, H. D. Fuller and M. B. Dolorich, J. Chromatogr. Biomed. Sci. Appl., 645 (1994) 205. doi: 10.1016/0378-4347(93)e0457-2

17. S. Emara, T. Masujima, W. Zarad, M. Kamal, M. Fouad and R. El-Bagary, J. Chromatogr. Sci., 53 (2015) 1353.

doi.org/10.1093/chromsci/bmv024

18. M. Dolezalova and M. Tkaczykova, J. Pharm. Biomed. Anal., 19 (1999) 555. doi:10.1016/S0731-7085(98)00257-x

19. K.C.Chang,Y. T.Chang and C.E.Tsai, J. Fo. Dru. Anal., 26 (2018) 725. doi.org/10.1016/j.jfda.2017.09.005

20. M. Amare and G. Menkir, Heliyon, 3 (2017) e00417. doi.org/10.1016/j.heliyon.2017.e00417

21 A. Salmanipour, M. A. Taher and $H$. Beitollahi, Anal. Methods, 4 (2012) 2982. doi:10.1039/c2ay25459j

22. N. L. Ghanis, M.S. Rizk and R. M. El-Nashar, Anal. Lett., 35 (2002) 39. doi:10.1081/al-120002360

23. I. Dol and M. Knochen, Talanta, 64(2004) 1233. doi.org/10.1016/j.talanta.2004.04.040

24. T. Maiihieu, B. Debora and R. J. Augusto, Anal. Lett., 39 (2006) 327. doi: $10.1080 / 00032710500477050$

25. H. Filik, İ. Şener, S. D. Cekiç, E. Kilic and R. Apak, Chem. Pharm. Bull., 54 (2006) 891. doi: $10.1248 / \mathrm{cpb} .54 .891$

26. H. H. Willard, L. M. Merrit and J. A. Dean, Instrumental Methods of Analysis, $5^{\text {th }}$ ed., D. Van Nostr and Company, New York, (1974) 121. doi: 10.1016/0022-2860(77)85072 
27. L. G. Hargis, Analytical Chemistry, Prentice-Hall, Inc., New Jersey, (1988) 424. $\underline{\mathrm{RN}}: 21030401$

28. British Pharmacopeia, Incorporating the $7^{\text {th }}$ Ed. of the European Pharmacopoeia, CD Rom, (2013), $7^{\text {th }}$ ed., Version 17.
29. M. M. Ayad, H. E. Abdellatef, M.M. Hosny and N. A. Kabil, Nano Biomed. Eng., 10 (2018)16. doi: 10.5101/nbe.v10i1

30. E. A. Gadkariem, Saud. Pharm. J., 17 (2009) 289.

doi: $\underline{10.1016 / j . j s p s .2009 .10 .005}$ 